\title{
REMORSE AND REPENTANCE STRIPPED OF ITS VALIDITY. AMNESTY GRANTED BY THE TRUTH AND RECONCILIATION COMMISSION OF SOUTH AFRICA ${ }^{182}$
}

\section{Eugene Baron ${ }^{1}$}

Department of Christian Spirituality, Church History and Missiology University of South Africa

barone@unisa.ac.za

\section{ABSTRACT}

During the South African amnesty process perpetrators would get amnesty if they could prove that there was a political motive for committing their actions, their deeds were proportionate, that they happened during and between the years 1960 and 1994, and if they gave full disclosure. The purpose of this article is to demonstrate the following: the fact that remorse and repentance were not required in order for perpetrators to get amnesty, left the reconciliation process in a vacuum. The inclusion of remorse and repentance as a requirement for amnesty, would have established a true (not a cheap) forgiveness and a 'thick' reconciliation process between perpetrators and victims. Remorse and repentance would have requested an admission and regret of wrongdoing, followed by an act of repentance underwritten by acts of contrition.

Key words: Truth and Reconciliation Commission; South Africa; amnesty; remorse; repentance.

\section{Introduction}

One of the most common challenges in our society is that of reconciliation and forgiveness. James and Van de Vijver (2000) refer to the attitude of a former president of South Africa, in the context of reconciliation, stating: 'De Klerk had no remorse

\section{UNISA}


and seemed to be offended, as if South Africa and the world could not appreciate the greatness of his deed.' In similar vein the words of a former president P.W. Botha who made news headlines are also quite ironical: 'I am not a fool. I made many mistakes, but I ask God on my knees for the light to come. An Afrikaner doesn't go on his knees before people; he does it before God' (cited in Krog 1998, 266).

The above review and quotes by prominent figures in South Africa highlight the gap within the system - the exclusion of remorse and repentance as a core element in granting amnesty. The element of remorse is echoed by a previous Minister of Finance in South Africa, Trevor Manuel, who was also part of the transitional government at the time: 'The faculty of remorse... is vital for genuine reconciliation' (Asmal, Asmal and Roberts 1996, 47).

An analysis of the South African TRC Final Report (1998, Vol. 6, sect 1, chp. 1, p. 4) regarding the amnesty of perpetrators, exhibits the official requirements for granting amnesty to perpetrators who had committed crimes under and as a result of the apartheid government in South Africa. The formal requirements for amnesty by the South African TRC were: 1) That the crime committed constituted an act associated with a political objective as envisaged in the Act; and 2) That the applicant give full disclosure of all the relevant facts.

The requirements for amnesty, as reflected in the Act of National Reconciliation and Unity, No. 34 of 1994, show that remorse and repentance were not requirements for granting amnesty to perpetrators by the South African TRC. The questions which could be raised, are: If the core aims of the TRC were reconciliation and forgiveness, is it not vital to also include remorse and repentance as part of restoring victimperpetrator relationships? Moreover, with the current requirements as set out in the Act of National Reconciliation and Unity, No.34 of 1994, did the process of amnesty promote healthy victim-perpetrator relationships, or did the process of granting amnesty impede this kind of relationship? In the final instance, and in hindsight, if remorse and repentance had been included in the requirements, what would the projected results have been?

This article purports an understanding that the exclusion of remorse and repentance as official requirements in the amnesty process brought about an incomplete reconciliation between victims and perpetrators. Furthermore the article will show how (because of this gap) injustices sneaked into the process of reconciliation in South Africa. The arguments in the article will expose the lack of justice in the process of amnesty, which was supposed to be spearheaded by the TRC of South Africa. In building the abovementioned argument the article will analyse the relevant elements of the modus operandi of the South African TRC, and the events that occurred during the time when the Commission was in operation.

The author believes that the amnesty process became an opportunity for some perpetrators who were scared and afraid of the consequences of their deeds, as a way to escape the full responsibility of their actions, rather than to reflect on the effects that their deeds had on the victims and how the atrocities committed, crippled the 
lives of victims in such a manner that many of them would not be able to uphold a comfortable lifestyle like the perpetrators. One of the most common themes in our society is that of reconciliation and forgiveness. This article intends to illuminate the important elements of 'remorse and repentance' as crucial to the forgiveness and reconciliation process.

This paper contends that the incorporation of these vital elements (remorse and repentance) in the South African TRC amnesty process, but also any other institution or individual's task when pursuing reconciliation and forgiveness, will definitely enhance reconciliation and also contribute to the quality, authenticity and sincerity of mutual relationships. It will also lead to the removal of enmity, hatred and bitterness. In order for a society to be restored and imbued with unity, there should not only be an agreement, political compromise or a 'negotiated settlement' reflected on papers and reports, but the type of reconciliation that the author reflects in this article, is a change of heart through the showing of remorse and repentance. This change of heart needs to materialise through the future actions of the perpetrator.

The article will start off with a description of the reconciliation process of the $\mathrm{TRC}$, and continue to analyse the process of reconciliation and forgiveness and the absence of remorse and repentance. The author then turns to the amnesty process itself, showing the results that the omission of these two elements holds for victimperpetrator relationships. The article will also reflect, in hindsight, what the results would have been if these two elements had been made part of the requirements for amnesty.

\section{The South African TRC striving for reconciliation and forgiveness in the absence of remorse and repentance}

\section{The pursuit of reconciliation in the absence of remorse and repentance}

According to Anderlini, Conaway and Kays (2014), reconciliation varies in meaning and significance. It can simply mean co-existence or dialogue, remorse, apology, forgiveness and healing.

The TRC explained in their final report what they understood under the concept of reconciliation. The concept of reconciliation, according the TRC, was both a goal and process (TRC Final Report 1998, Vol. 1, chap 5). Despite this definition, Borer $(2004,30)$ points out that the TRC:

... was given little guidance from either the interim constitution or its founding act on how to interpret the core concept at the foundation of its mandate: promoting reconciliation in South Africa. The commission therefore had to develop its own understanding of reconciliation. The grappling with the concept could also be seen in the way Archbishop Desmond Tutu referred to the reconciliation at the end of the TRC process. He noted that "the objective of the TRC was to promote reconciliation and not to achieve it". This is indeed contrary to their 
report, which regards reconciliation as the goal of the overarching TRC process. However this goal of reconciliation was diminished to - just the starting point of a much larger process to attain reconciliation. (Borer quoted in Sarkin 2004, 219)

Instead of examining the causes by which individual and national reconciliation was hampered during the TRC process, they settled for merely understanding reconciliation as a possible future achievement, and not one that could be attained at the end of the TRC's processes. The argument of the TRC, that reconciliation was not necessarily achievable at the end of their processes, is not the main issue at stake, but rather the fact that they failed to reflect on issues such as remorse and repentance, which could have played a pivotal role in achieving reconciliation.

In fact, there were many instances where they could have used moments where it (remorse) surfaced; to ignite it and incorporate it within its operations. Sarkin (2004, 226) speaks of occasions when reconciliation took place, in what he calls 'magic moments' in the TRC process, when perpetrators and victims came together and remorse was expressed and forgiveness was offered. However, these moments were not as common as they could have been.

Reconciliation is not an unrelated concept to remorse and repentance; it is indeed part of the process of making peace with the victim, by an understanding and acknowledgement of wrongs committed and a re-evaluation by perpetrators of their morality (Asmal et al. 1996, 47).

Therefore, the fact that most perpetrators did not even understand that what they had done was immoral, indeed posed an impediment in bringing forth adequate reconciliation. They were granted amnesty without even re-evaluating their immoral behaviour and examining their behaviour through moral lenses. If perpetrators envisaged themselves through the eyes of the other (victims), such a process could have brought about a deep sense of wrongdoing (remorse), but also active involvement in the reparations and the healing of the wrongs committed. They would have been encouraged to make things right with their counterparts as part of the reconciliation process (Asmal et al. 1996, 47).

Botman and Petersen $(1996,80)$ provide us with a Biblical analysis of the concept of reconciliation, and according to them reconciliation implies the removal of hostilities and the restoration of a fellowship of peace. Reconciliation denotes wholeness and is therefore closely linked to the Hebrew word shalom.

Olson $(1997,120)$ refers to un-reconciled persons as 'lost' persons, as reflected in Jesus' teachings. He describes Jesus' mission to the un-reconciled when stating:

When He called sinners to repentance, it was an invitation to individuals to change so that they were able to become who they truly are; it was not merely a call to relieve their feelings of guilt or to modify their behaviour.

Important consideration should be given to the concept of reconciliation as well as that of repentance and remorse referred to by Olson in the previous quote. But Olson (1997) also makes a distinction between repentance and remorse. Although 
these two elements are both important in the reconciliation process, the distinctive character should be noted. In the case of various TRC hearings the emphasis was on the presence of catharsis, which implied the 'relief of depressed feelings', and not the type of remorse that Olson refers to in the abovementioned assertion. Olson $(1997,20)$ refers to a changed behaviour (repentance) that emanates from a feeling of remorse. Catharsis is insufficient for establishing a 'thick' process of reconciliation between victims and perpetrators, therefore more is needed - remorse and repentance.

The question is not exclusively if reconciliation has been achieved or not, but the question could also be posed how far the process of reconciliation has progressed. As promoters of the reconciliation process, we take note of the TRC report which states that the TRC was not meant to achieve reconciliation but rather to contribute to the process. In contrast, Schreiter $(1998,14)$ remarks: 'God initiates the work of reconciliation in the lives of the victims. It is thus also God who opens the eyes of the other to see himself as God sees him; this would bring about a remorseful, repentant sinner, receptive for God's forgiveness, but also in human relationships.' Schreiter $(1998,14)$ also wishes to think differently about the paradigm of reconciliation. He states:

Ordinarily we would expect reconciliation to commence with the repentance of the wrongdoers. But experience shows that wrongdoers are rarely willing to acknowledge what they have done or come forward of their own accord. If reconciliation depended entirely upon the wrongdoer's initiative, there would be no reconciliation at all.

Schreiter (1998) thus gives reconciliation a different paradigm than the conventional one. 'It is through the victim that the wrongdoer is called to repentance and forgiveness. Seen from this perspective, repentance and forgiveness are not the preconditions for reconciliation, but are rather the consequences of it' (Schreiter 1998, 15). Schreiter $(1998,13)$ in his book The ministry of reconciliation, expresses his view regarding the Christian understanding of reconciliation. He explains:

Some cultures have a very distinct concept of reconciliation that is expressed ritually: an accusation of wrongdoing is levelled at someone, that person acknowledges the wrongdoing and apologizes in some formal way, the apology is accepted by the community, and the wrongdoer is ritually re-integrated into the community, signifying forgiveness.

In most cases during the amnesty process, wrongdoers admitted their guilt because it was for their own benefit and the prospect of receiving amnesty. When evaluating the TRC process in terms of Schreiter's understanding of reconciliation, perpetrators did acknowledge their wrongdoing, because full disclosure was a requirement, but the other aspect 'to apologise' was not articulated as part of the reconciliation process of the South African TRC.

Borer $(2004,23)$ in his review on the South African TRC argues that there is no single meaning of the concept 'reconciliation'. In fact, he distinguishes between 
two models of reconciliation. The first he classifies as interpersonal or individual reconciliation, while the other is best described as 'national unity and reconciliation'. The first model is associated with either a religious or medical paradigm, while the second model is closely related to a political one (Borer 2004, 25). The TRC Final Report (1998) proclaimed to have focused on both these models. According to the report handed in by the TRC to former President Nelson Mandela in October 1998, the TRC was promoting reconciliation on a national and on an individual, personal level.

Borer $(2004,25)$ asserts that: 'The best that can be hoped for in the national unity and reconciliation process is enhanced peaceful coexistence. He assumes that former enemies are likely to agree with each other or even to get along very well.' But what brings national unity is not exclusively seen as restoring individual relationships. It is in this regard that Borer $(2004,24)$ asserts:

The language associated with "individual reconciliation" can be found throughout the TRC Report. In the foreword to the multi-volume report, TRC chairperson Archbishop Tutu asserts that, "the key concepts of confession, forgiveness and reconciliation are central to the message of this report".

Finally reconciliation is regarded as:

... a multidimensional, unifying experience of resolving conflicts within and among alienated persons, whose being and relations are transformed through the power of forgiveness and the process of compassionate confrontation into a healing reunion of love, justice, and peace for the sake of which one decides to intentionally act. (Olson 1997, 99)

This definition includes interpersonal relationships and a person's own personal being or personhood to be transformed through the act of reconciliation.

After a brief analysis of the goal of reconciliation, this article will now move to another goal as envisaged in the mandate of the South African TRC, and that was to bring about forgiveness. This in itself, although not an official goal, could never be achieved in the true sense of the word without taking into account the factors of remorse and repentance. The following section will closely investigate the South African TRC's pursuit of forgiveness in the absence of remorse and repentance.

\section{The pursuit of forgiveness in the absence of remorse and repentance}

In the TRC Final Report (1998), in the chapter on 'Concepts and Principles', forgiveness sorts under the second level (victim and perpetrators) which is concerned with forgiveness and healing between victims and perpetrators (Borer 2004, 28). Whenever reconciliation is pursued, forgiveness inevitably becomes part of the process. By implication it means that without forgiveness there can be no reconciliation. The South African TRC had also as their goal the presence and manifestation of forgiveness between victims and perpetrators. It is therefore of 
paramount importance to underscore the presence of remorse and repentance in the process of forgiveness.

It later became known in various newspapers that victims claimed they were being forced to forgive their perpetrators. Verwoerd $(1999,305)$ refers to a young South African woman saying: 'What really makes me angry about the TRC and Tutu is that they are putting pressure on us to forgive. For most black South Africans it is about us having to forgive...I don't know if I will ever be ready to forgive.'

Forbes (cited in Verwoerd, 1999, 318) (cf. TRC Final Report, Vol. 1:115-117) argues:

Forgiveness should be encouraged, perhaps in the first place, as an antidote to the poison of unresolved bitterness and repressed resentment, as a call to those violated to liberate themselves from the poison of victimhood...for the sake of themselves, their children and the rest of society.

Smedes (cited in Botman and Petersen 1996, 109) says that: 'One must forgive for one's own sake, for the sake of one's own spiritual health and one's own future.' Smit (cited in Botman and Petersen 1996, 109) argues that forgiveness should be granted, for our own sake, even to those that are unrepentant. He argues: 'We need to forgive people...so that we do not drown in our own misery. Let the other guy take care of himself.'

Gregorowski $(2003,3)$, however, slightly differs from the views of Smedes and Smit. She argues that 'a range of factors may contribute to forgiveness, including apology or remorse on the side of the perpetrator, and on the forgiver's side, compassion, understanding, as well as a conscious decision to "let go" of bitterness and hatred without any expectation of apology or remorse from the perpetrator.' Gregorowski (2003) suggests that remorse and apology are essential, but the victim should not be controlled by the perpetrator and become dependent on their remorse or apology.

Furthermore, Gregorowski (2003, 5) utilises the argument of Lamb and Murphy (2002) who argue that forgiveness of a perpetrator in the absence of remorse or apology is damaging to a victim's self-respect, violates their moral and human integrity and may serve to reinforce their victimisation. This illuminates our overarching problem that the omission of remorse, even in the process of forgiveness, has major repercussions on victims.

A further argument is the inclusion of repentance in the process of forgiveness to achieve reconciliation. Augsburger $(1996,16)$ regards repentance as being central to the process of forgiveness and argues that: 'Cheap grace is the preaching of forgiveness without requiring repentance.'He refers to this reciprocal action as mutual forgiveness, which according to Augsburger $(1996,14)$ encompasses the mutual recognition that repentance is genuine and right relationships have been restored or achieved. Augsburger $(1996,16)$ sums up his understanding of forgiveness when 
he states: 'Forgiveness is the recognition that repentance is intended, embraced, pursued. Love may be unconditional; forgiveness is not.'

In similar vein of the view by Augsburger $(1996,16)$ that forgiveness and repentance go hand in hand, James and Van de Vijver (2000) raise their disappointment in the former head of state concerning the process of forgiveness. 'Mandela's willingness to forgive was never reciprocated by De Klerk's confession. On the contrary; De Klerk behaved as if forgiveness was his due.' Maluleke (2001, 196) elaborates: ' $\ldots$ an important failure of the TRC process was, namely its failure to call leaders and thinkers (and not just the dozens of foot-soldiers) to account for and hopefully repent of their role in implementing apartheid.'

Also Lapsley $(1996,22)$, a well-known supporter of forgiveness, argues as follows:

Forgiveness, yes - that is always the Christian calling - but no one should suggest that forgiveness is glib, cheap or easy.

In an assessment of the place of forgiveness in the South African TRC process, this article concludes with the words of Gobodo-Madikizela (cited in Gregorowski, 2003, 5) with regards to forgiveness:

... forgiveness is conditional upon remorseful regret, two important factors in forgiveness... are remorseful apology... and acknowledgement of wrongdoing; asking for forgiveness without an attempt to appreciates the other's pain, without making a human connection with the other person, has an empty ring to it.

The underpinning factor in this section is to argue that the reward of remorse and repentance is forgiveness. A person who avails himself of remorse and repentance can confidently await forgiveness. When the TRC of South Africa sought forgiveness, it was imperative for them to include these elements, which would have also contributed to the overall authenticity and integrity of the process.

On the basis of this, the following discussion will move closer to the Amnesty Committee itself and their role in omitting remorse, and how they promoted or impeded healthy victim-perpetrator relationships. Then the last section, which will be more eschatological in nature, will draw on the events of the Amnesty Committee and will discuss if they had indeed included these two elements (remorse and repentance); what would the projected outcome(s) have been?

\section{The Amnesty Committee and the issue of remorse and repentance}

The South African TRC never intended to function as a religious commission, albeit that Archbishop Desmond Tutu, as an Anglican priest, was the chairman. The South African TRC was a vehicle for the state to establish national unity and reconciliation 
in a country with much division. The Amnesty Committee surpassed twelve other TRC commissions in the world, due to the fact that it was the only commission in its time to do away with blanket amnesty. In this instance the South African TRC with its Amnesty Committee was distinct in relation to other TRC commissions elsewhere.

The appointments made to the Amnesty Committee were made exclusively from the ranks of the legal profession (TRC Final Report, 1998, 85). They appointed judges, advocates and attorneys. This was conducive to establish a legal atmosphere. Between the three committees that existed within the South African TRC (that is the Human Rights Violations Committee, the Reparation and Rehabilitation Committee, and the Amnesty Committee) the Amnesty Committee was the only one that could implement its decisions promptly, while the Reparation and Rehabilitation Committee could only make suggestions.

From the outset it is important to notice that because remorse and repentance were not part of the conditions and requirements to apply for amnesty, as set out in the founding Act of National Reconciliation and Unity, No. 34 of 1994, it was merely an act of goodwill when perpetrators showed remorse and repentance. Hence there were occasions when the TRC attempted to achieve reconciliation, particularly when Archbishop Tutu took the lead, and at times remorse and repentance featured strongly (Sarkin 2004, 213). One of the occasions was at the St. James hearings, when an amnesty applicant, Gcinikhya Makoma stated: 'We are sorry for what we have done... We are asking you, please do forgive us. All that we did, we can see the effects today' (Sarkin 2004, 225). Mostly, however, repentance did not feature as part of the amnesty process at all.

Although the apartheid government under the leadership of former president F.W. de Klerk initiated the process of establishing a new democratic government by starting negotiations with Nelson Mandela (after his speech in Parliament during February 1990), there was never an admittance of wrongdoing or a sense of remorse or repentance that surfaced (Maluleke 2001, 196) from the apartheid government. It is said that one of the reasons why the apartheid government decided to start the negotiations with the ANC and other parties, was because they were under immense pressure from the United Nations and the international community to lift the economic sanctions on South Africa. This is therefore regarded as one of the reasons that drove the apartheid government in South Africa to commence with the negotiation process ${ }^{2}$ with all the banned parties at the time. Therefore the reaction of Lapsley $(1996,20)$ speaks to the negotiated process in South Africa. Lapsley, who was also a victim under the apartheid government, conveyed his disappointment in the fact that even during the deliberations of the Convention for a Democratic South Africa (CODESA) there were no official statements or words of repentance or acknowledgement of evil. The example and attitude of the apartheid leadership paved the way for their retinue. It is therefore not surprising that their foot-soldiers, those on grass-root level, also followed in their path. When the South African TRC 
reported $(1998,90)$ on the attitudes of perpetrators during the amnesty hearings, they stated:

Perpetrators' attitudes ranged from taking pride in their past actions, to disavowing any further support for their earlier attitudes, to expressions of deep remorse. Often they had to experience the humiliation of public exposure of their shameful pasts. Others said that they would probably repeat what they have done in similar circumstances.

According to their feedback on the attitudes of perpetrators during the hearings, the TRC reported that to some extent remorse was present, but in other cases it was absent. It is also evident when studying the TRC Final Report (1998) in this regard that although there was intense catharsis expressed by the perpetrators during the public hearings, what was often missing in some cases is not only compunctious behaviour, but remorse that leads to repentance.

Despite the obvious lack of repentance and remorse, as reflected in the TRC Final Report (1998), there was indeed a process which opened up the space for remorse and repentance to surface, though I argue that it was in a limited sense. In the book Carrots and sticks, Sarkin $(2004,238)$ refers to a reconciliation register that was provided by the South African TRC where remorseful perpetrators could express their remorse. The shady part of this type of reconciliation between victims and perpetrators is that even if it may promote reconciliation, it will happen behind closed doors.

The fact that perpetrators needed to confess their wrongdoing was a small step in the direction of remorse and repentance (Sarkin 2004, 238). In most cases, where perpetrators denied their guilt, amnesty was declined (Sarkin 2004, 245).

Because the Amnesty Committee slots into the aims and goals of the whole Commission, which is reconciliation and forgiveness, the question often grappled with is: Did the amnesty committee promote or impede restored victim-perpetrator relationships? This is the question that needs to be discussed critically, and we will draw conclusions out of this instance with regard to the process of reconciliation and forgiveness.

\section{Did the amnesty committee promote or impede restored victim-perpetrator relationships?}

In the foreword by Desmond Tutu, in the Final Report of the South African TRC (1998), he states:

Amnesty applicants often confessed to more gruesome crimes than were the subject of the Basson trial, yet their assumption of responsibility and the sense that at least people were getting some measure of truth from the process, resulted in much less anger. (TRC Final Report, 1998, Vol. 6: 6) 
This extract from the foreword of the chairman of the Commission, clearly expressed the aim of the South African TRC as well as the Amnesty Committee; and that is the emergence of truth. Reconciliation, however, which was also one of the core aims of the Act of National Reconciliation and Unity, No. 34 of 1994, was not vividly and vehemently expressed by the chairman but rather tentatively. I quote:

All of us South Africans must know that Reconciliation is a long haul and depends not on a commission for its achievement but on all of us making our contribution. It is a national project after all is said and done.

The chairman made this statement when he took a moment to recall the progress in attaining reconciliation on a national level (Borer 2004, 25). For Tutu the success lay therein that they provided a space for everyone to tell their narrative. His statement also shifts the responsibility to attain reconciliation from the TRC to the rest of South Africans. Despite these comments made by Tutu, we should not forget that this Commission's mandate was to reconcile. Even the Amnesty Committee with its mandate to grant amnesty to perpetrators, needed to slot in with the overarching aim of the TRC.

The Amnesty Committee as part of the South African TRC was only creating space(s) for perpetrators to tell their narrative and truth. What thus seems to be the disturbing issue is the fact that amnesty is the perpetrator's reward for giving full disclosure. Verwoerd $(1999,311)$ refers to Boraine, Deputy Chairperson of the South African TRC, who says: 'Amnesty is the price we have to pay for peace and stability.' In this sense the Commission argued that the truth was important for the nation as well as the individual in order to achieve reconciliation. Although I agree that truth is important in the reconciliation process, and for granting amnesty, I only agree partially. The question remains: Why did the Amnesty Committee fulfil the goals (reconciliation and forgiveness) of the TRC, and negotiated for truth at the expense of expression of remorse and repentance from the perpetrators?

Verwoerd $(1999,313)$ writes on restorative justice as the approach followed by the TRC. The approach underscored the uncovering of truth and was central to the reconciliation process. He writes:

Reintegrative punishment tries to bring shame and personal and family community responsibility back into the justice process: instead of just "doing my time", offenders through negotiated community responses - are given opportunities to understand and acknowledge their crimes, to take responsibilities and make things right.

A further question arises: If truth was the South African TRC's main purpose in the process of attaining national and individual reconciliation, where is the 'make things right' (repentance) part that Verwoerd refers to as part of restorative justice and truthtelling from the perpetrator? Anderlini et al. (2014) wrote an article Transitional justice and reconciliation in which they mention the elements of restorative justice - the type of justice implemented by the TRC. Anderlini et al. (2014) remark: 'Truth 
telling and the meeting of victims and perpetrators are important in the process, as are expressing remorse and making restitution to the victim and his or her family.' It needs to be noted that the latter elements (expressing remorse and making restitution) are just as important as truth-telling. The TRC proved by their feedback in the TRC Final Report (1998) that they placed the emphasis strongly on truth-telling, while neglecting remorse and restitution as part of the restorative process between victims and perpetrators.

This paper argues that when we want to promote victim-perpetrator relationships, remorse and repentance are imperative. Augsburger $(1996,10)$ in his book Helping people forgive, comments:

It is not our capacity to think that makes us different, but our capacity to repent, and to forgive. Only humans can perform that most unnatural act, and by doing so only they can develop relationships that transcend the relentless law of nature.

While this section pointed out the gap (remorse and repentance) in seeking healing of victim-perpetrator relationships, the next section will try to look forward by addressing the question: What would have been the status of victim-perpetrator relationships if remorse and repentance were made part of the amnesty process?

\section{Remorse and repentance: Prerequisites for amnesty?}

Showing remorse was not an official requirement for amnesty, and repentance was not articulated throughout the South African TRC process at all (Dorsman, Hartman and Noteboom-Kronemeijer 1999, 67), although the author admits that there were small instances and expressions of remorse and a seeking for forgiveness on the part of some of the perpetrators who applied for amnesty (Borer 2004, 25).

Repentance has, in Christian traditions, consisted of three dimensions: remorse, restitution and renewal. First a genuine sorrow is necessary; secondly an attempt to restore what was destroyed as far as possible; and thirdly a change in life direction (Borer 2004, 25).

Besides the Amnesty Committee the Reparation and Rehabilitation Committee dealt with restitution as part of the reconciliation process of the TRC. An interim compensation with immediate effect, which should bring immediate relief, of an amount of five hundred thousand rand was provided to the victims. Medical benefits were also made available to victims and their respective families. However, nowhere in the process of amnesty were perpetrators required to take responsibility and make a contribution, whether financially or by any other means to restore the relationship between them and the victim(s). Another way of arguing is that perpetrators are tax payers and that in that sense they contributed to the compensation for the hurt, pain and suffering of the victims. This article does not agree with such a way of contributing to the crippled lives of victims, as it does not involve any initiative from the side of the perpetrators. A remorseful and repentant action from perpetrators 
would mean that even after the state had compensated for the pain and suffering of victims, perpetrators would continue to interact with the victims and look at possible ways to reconcile and set things in the right order (in the sense of distributive justice). Verwoerd (1999) comments:

The fact that people are given their freedom without taking responsibility for some form of restitution remains a major problem with the amnesty process. Only if the emerging truth unleashes a social dynamic that includes redressing the suffering of victims will it meet the ideal of restorative justice.

From a Biblical perspective the book of Acts is reminiscent in this regard. The early church was relinquishing; selling their goods to bring equilibrium within the community of believers. Another example of economic justice is found in the Old Testament Scriptures, during the year of Jubilee every $50^{\text {th }}$ year (Botman and Petersen 1996, 86). Wolfram (cited in Botman and Petersen 1996, 86) asserts:

The setting of the announcement of the Jubilee in the atonement day was an acknowledgement of the sinfulness inherent in the accumulation of wealth in the hands of a few which had to be rectified again and again. In the announcement of the kingdom of God by Jesus the jubilee tradition pertains not merely to the redistribution of resources and the restoration of the freedom of the people of God every fifteenth year. It also pertains to the daily life of a Christian. Every day the Christian is to draw strength from the amnesty brought about by God through Jesus and every day the believer is bound to pass on this amnesty to fellow human beings. (Botman and Petersen 1996, 87)

Everett (cited in Cochrane, De Gruchy and Martin 1999, 159) adds: 'With regard to the work of building up a new constitutional order the Jubilee enjoins a common effort to provide everyone with the necessities of life in community.'

To answer the question if the praxis of 'Jubilee' would be an excellent way to reflect a remorseful and repentant individual and society, the answer would be affirmative.

This section underscored the successful results between perpetrators and victims when remorse and repentance are part and parcel of the process of reconciliation. The process of reconciliation was a learning curve for the South African government and the appointed TRC to achieve its purpose of reconciliation and forgiveness. With all its success the South African TRC needs to be humble enough to admit that the reconciliation process lacked remorse and repentance, and to acknowledge that the inclusion of these two elements (remorse and repentance) would have strengthened the authenticity and integrity of the reconciliation process.

\section{The role of the church}

The notions of repentance and remorse are well articulated within the resources of the various religions and faith communities in South Africa. It is well documented within their authoritative scriptures, writings and sayings from respected figures and 
deities. In the Christian tradition, which is mainly regarded as one of the prominent religions in South Africa, the notions of remorse and repentance are central. It is often quoted from Old and New Testament passages of the Christian Bible. Botman and Petersen $(1996,12)$ rightly assert: 'There is little question about the need of the church and Christian theologians to accompany the TRC process because the notion of truth and reconciliation lies at the heart of the Christian tradition, therefore "truth" and "reconciliation" is our job.' It was indeed the Christian approach in the operation of the TRC that created much tension between those who tried to create at every public hearing a religious atmosphere, and those who felt that the public hearings should not be regarded as a church service or a religious gathering (Meiring 2002, 329-330).

Despite the concern from politicians, academics and others who served on the South African TRC at the time when the Commission was in operation, there was a religious (some would say more 'Christian') atmosphere present at the public hearings. This happened as a result of various aspects such as the singing of hymns at most hearings, the opening and closing of the hearing with prayer, which became the norm after the opening prayer of the chairperson Archbishop Desmond Tutu at the first hearing in East London. What would we expect if the churches were 'overrepresented' on the Commission? (Meiring 2002, 331; cf. Maluleke 1997a, 59).

Meiring $(2002,332)$ also reminds us that we should bear in mind that the context of South Africa was more religious in nature, and that one should not be surprised if the South African community deals with their pain and hurt in a religious fashion, instead of dealing with it in a clinical way. Meiring $(2002,333)$ emphasises the religious context of South Africa when he refers to Tutu who stated: 'Religion is central to the process of healing.' Meiring $(2002,332)$ reports that during the TRC process, from the onset, the faith communities were involved with the 'drafting of the TRC Act', though we are also aware that according to the Act of National Reconciliation and Unity, No. 34 of 1994, the TRC was indeed judicial in nature rather than spiritual or religious (Maluleke 1997a, 65). Taking all this into consideration, and based upon the analysis of the church and faith communities by Meiring as one of the Commissioners of the South African TRC, I am surprised that the same insistence for an opening of prayer at all the public hearings (by the chairman Archbishop Tutu at the hearings where he was present), that he or other religious and faith communities did not show the same insistence on issues of remorse and repentance, which are central to the church and most religions in South Africa, as official requirements for amnesty.

\section{Conclusion}

The point emphasised in this article is that reconciliation and forgiveness was one the goals of the South African TRC. We then reflected on the role that remorse and repentance should play in attaining these goals, and it was shown that if reconciliation 
and forgiveness are not part of the reconciliation process, it will create a gap in the process. Then the author moved on to analyse the amnesty process by reflecting on two questions: Why did the amnesty committee require only truth without including remorse and repentance? This leads to a future view of a TRC that would include these two elements. By doing this, the author wishes to contribute positively to future processes of reconciliation in South Africa - and through his own contribution, envisages possible outcomes and consequences - should remorse and repentance have been made part of the TRC amnesty process. Finally, the author analysed the role of the church, religions and faith communities, and the crucial role that they should have played in introducing and insisting on the inclusion of remorse and repentance within the TRC process, as they did with the TRC 'liturgy' (cf. Meiring 2002, 332). Though the South African TRC processes are completed, the church can still seek ways to ignite and create moments and spaces where acts of remorse and repentance can manifest. I therefore conclude by placing my concern next to that of Petersen (cited in Maluleke 1997b, 326), in asking: Is this not what happened during the amnesty process of the South African TRC; the failure to include remorse and repentance as official requirements that Bonhoeffer would refer to as cheap grace, that demands neither repentance nor conversion (or remorse) of attitude and life which it seeks?

\section{ENDNOTES}

1. There were also other truth and reconciliation commissions; however, this one was the only commission that did not grant blanket amnesty, but amnesty under certain conditions. In the rest of the article whenever it is referred to the TRC it refers to the South African Truth and Reconciliation Commission.

2. This article was presented as a conference paper at the annual South African Missiological Society's (SAMS) conference in Mafikeng, 2014.

3. Rev. Eugene Baron is a lecturer in the Department of Christian Spirituality, Church History and Missiology at the University of South Africa (Unisa).

4. This process was known as the Convention for a Democratic South Africa (CODESA).

\section{LIST OF REFERENCES}

Act of National Reconciliation and Unity, No.34 of 1994. Pretoria: Government Printer.

Anderlini, S.N., C.P. Conaway and L. Kays. 2014. Transitional justice and reconciliation. https:// www.huntalternatives.org (accessed on 2009/08/15).

Asmal, K., L. Asmal and R.S. Roberts. 1996. Reconciliation through truth. A reckoning of apartheid's criminal governance. Cape Town: David Phillip Publishers. 
Augsburger, D.W. 1996. Helping people forgive. Louiseville, Kentucky: Westminster John Knox Press.

Borer, T.A. 2004. Reconciling South Africa or South Africans? Cautionary notes from the TRC. African studies Quaterly, Vol. 8(1): 19-36.

Botman, H.R. and R.M. Petersen. 1996. To remember and to heal. Cape Town: Human and Rousseau Publishers.

Cochrane, J., J. de Gruchy and S. Martin. 1999. Facing the truth. South African faith communities and the Truth and Reconciliation Commission. Cape Town: David Phillip Publishers.

Dorsman, R., H. Hartman and L. Noteboom-Kronemeijer. 1999. Truth and reconciliation in South Africa and the Netherlands. Netherlands Institute of Human Rights.

Gregorowski, C. 2003. Understanding forgiveness in the context of political violence: Five case studies from South Africa. Honours Research Project. Cape Town University.

James, W. and L. van de Vijver. 2000. After the TRC: Reflections on truth and reconciliation in South Africa. Cape Town: David Phillip Publishers.

Krog, A. 1998. Country of my skull. South Africa: Random House Publishers.

Lamb, S. and J. Murphy. eds. 2002. Before forgiving: Cautionary views of forgiveness in psychotherapy New York: Oxford University Press.

Lapsley, M.1996. Interview with Michael Lapsley (Trauma Center, Cape Town, November 12, 1996, unpublished manuscript.

Meiring, P.G.J. 2002. 'Pastors or lawyers? The role of religion in the South African Truth and Reconciliation Process.' HTS, Vol. 58(1): 328-339.

Maluleke, T.S. 1997a. 'Dealing lightly with the wound of my people? The TRC process in theological perspective.' Missionalia, Vol. 25(3): 324-343.

Maluleke, T.S. 1997b. 'Truth, national unity and reconciliation in South Africa. Aspects of the emerging theological agenda.' Missionalia, 25(1): 59-86.

Maluleke, T.S. 2001. 'Can lions and rabbits reconcile? The South African TRC as an instrument for peace building.' Ecumenical review, Vol. 53(1): 190-201

Olson, R.P. 1997. The reconciled life. A critical theory of counseling. London: Westport, Connecticut Publishers.

www.christchurchsummit.org (accessed on 3-11-2009).

Sarkin, J. 2004. Carrots and sticks: The TRC and the South African amnesty process. Cape Town.

Schreiter, R.J. 1998. The ministry of reconciliation. Spirituality and strategies. New York: Orbis Publishers.

TRC Final Report, 1998. Volume 1-6. Cape Town: CTP Book Printers.

Tutu, D. 1999. No future without forgiveness. New York: Doubleday Publishers.

Verwoerd, W.J. 1999. 'Toward the truth about the TRC: A response to key moral criticisms of the South African Truth and Reconciliation Commission.' Religion and Theology Journal. Vol. 3(3): 303-324. 